\author{
Joubert, SJ1 \\ Universiteit van die Vrystaat
}

\title{
Annus Virtualis: Enkele uitdagings wat die virtuele era van Web 2.0 aan relevante kerklike bedieninge stel
}

\begin{abstract}
Annus Virtualis: Some challenges that the virtual era of Web 2.0 face in terms of relevant church ministry

Annus Virtualis, the digital explosion presents nothing less than a global paradigm shift away from the mass print culture. This is illustrated by a short discussion of the meteoric growth of digital platforms such as Facebook, before focusing on the new "Net Generation." These "Net Geners" are transforming the digital world from a place where you search for information to an interactive social space where you share information and collaborate on projects of mutual interest, such as solving the globe's most pressing problems. After dealing with a few dangers the new virtual era poses for authentic social connectedness, the need for churches to wake up to the digital word and come to terms with authentic digital ministry is finally addressed.
\end{abstract}

\section{DIE ERA VAN VIRTUALITEIT IS HIER}

Annus virtualis, die era van virtualiteit is hier. Meer as een en ' $n$ half miljard mense wêreldwyd is reeds aanlyn bedrywig. Van die sowat 6,7 miljard mense op aarde is daar reeds oor die 1,8 miljard internetverbuikers aan die einde van 2009 , oftewel $26,6 \%$ van die totale wêreldbevolking. Dit verteenwoordig 'n groeikurwe van 399\% tussen 2000 en 2009. ${ }^{2}$ Meer as twee triljoen dollar se besigheid word jaarliks op die internet gedoen, terwyl $33 \%$ van alle boeke aanlyn verkoop word. Op 28 Mei 2010, met Google se bekendmaking van die grootste webruimtes in terme van internetverkeer, was Facebook bo aan die lys, met 540 miljoen unieke besoekers en 570 miljard bladbesoeke gedurende April 2010, terwyl Yahoo tweede was met 490 miljoen unieke besoekers. Wikipedia het 'n skaflike 310 miljoen besoekers gedurende dieselfde maand gehad. In Suid Afrika is News 24, wat internetverkeer betref, loshande die grootste webruimte met kort duskant 2,8 miljoen unieke besoekers gedurende Mei 2010. ${ }^{3}$

Die grootste suksesverhaal op die internet is ongetwyfeld Facebook, die breinkind van Mark Zuckerberg. As die jongste miljardêr in die geskiedenis is dit Zuckerberg se doel om Facebook as die planeet se basiese kommunikasie-platform daar te stel; oftewel as die gunsteling spasie waar mense hulle virtuele lewens deurbring. Wat aanvanklik begin het as ' $n$ eksperiment by Harvard Universiteit, waar Zuckerberg medestudente se foto's en kontak besonderhede aanlyn geplaas

1 Navorsingsgenoot, Departement Nuwe Testament, Universiteit van die Vrystaat, Bloemfontein

2 Internet World Stats: http://www.internetworldstats.com/stats.htm. In Junie 1993 was daar slegs 130 webtuistes, maar teen die middel van 2007 sowat 135 miljoen geregistreerde webblad name en 61 miljoen aktiewe webblaaie (Matthew Gray, aangehaal in Leadbeater, 2009:31).

3 Aldus Mybroadband.co.za: "The latest Nielsen Online website statistics showed that there was in fact no significant slowdown or growth in local website traffic... In June local OPA registered websites attracted 20,481,203 unique visitors..." http://mybroadband.co.za/news/internet/13493-South-Africas-top-localwebsites.html. 
het, het binne enkele jare gegroei tot ' $n$ formidabele virtuele ikoon met 'n beraamde waarde van \$15 miljard aan die einde van 2008. Facebook se groei gedurende die eerste kwartaal van 2009 was by die 5 miljoen mense per week, terwyl 140 miljoen nuwe lede reeds tussen Februarie 2007-Maart 2009 hier aangesluit het (Rice 2009:Kindle).

Nog ' $n$ uiters gewilde digitale kommunikasiemedium is Twitter wat in April 2010 reeds $105,779,710$ geregistreerde gebruikers gehad het. Via selfone en rekenaars kan mense 140 karakters per keer met hulle "followers" deel (of "tweet" soos wat dit bekendstaan). Teen 'n tempo van meer as 300,000 nuwe gebruikers wat daagliks hier aansluit en 180 miljoen unieke maandelikse besoekers wat sowat 55 miljoen tweets per dag versend, is Twitter met sy 175 werknemers ook ' $n$ beduidende rolspeler in die virtuele wêreld. ${ }^{4}$

Die internet het die informasie-ontploffing binne ons dag na nuwe hoogtes geneem, soos wat Joubert (2009:17-18) skryf:

"In 2006 is daar volgens Time Magazine 3 miljoen maal meer inligting in een enkele jaar op die www.wêreld van die internet versprei as wat daar in die ganse voorafgaande menseheugenis in boeke vasgevang is. Tans groei nuwe kennis teen sowat 2 miljard nuwe gigagrepe per jaar. Gedurende die afgelope 30 jaar is daar meer inligting in die wêreld geproduseer as in die voorafgaande 5,000 jaar. Reeds in 2005 het die internet se volume kennis elke 90 dae verdubbel, aldus Jane Alexander (The overload solution, 2005). Op sy beurt skryf Michael Le Gault (Think, 2006) daar is sowat 700 miljard dokumente in sirkulasie op die web terwyl daar elke dag kort duskant 7,5 miljoen nuwe webblaaie verskyn. Net op YouTube alleen is daar gedurende April 2009 meer inligting versprei en afgelaai as op die totale internet in die jaar 2000."

Ter wille van volledigheid moet ons onthou dat verwysings na die sogenaamde globale groei van die internet nie heeltemal in die kol is nie. Daar is ' $n$ groot kloof tussen Eerste- en Twee Derdes wêrelde wat internetbenutting betref. Tereg merk die godsdienssosioloë Dawson en Cowen (2004:5) op: "Any informed discussion of the Internet and its relationship to culture and society must give serious consideration to the division between the Internet haves and have-nots..." Wat Suid Afrika se internetgebruikers betref, het dit toegeneem vanaf 5,5\% in die jaar 2000, dit wil sê, vanaf 2,4 miljoen gebruikers binne 'n bevolking van 43, 690 miljoen inwoners na 10,8\% in 2009 , of 5,3 miljoen gebruikers binne 'n beraamde bevolking van 49 miljoen mense. ${ }^{5}$

\section{NIE FIKTIEWE WÊRELDE NIE, MAAR EERDER DIGITALE SOSIALE-KONSTRUKTE}

Eindelose voorbeelde sou uitgelig kon word rakende die fenomenale groei van die internet. Hopelik is die punt egter gemaak: Nuwe elektroniese en digitale tegnologie is tans'n onlosmaaklike deel van miljoene mense se daaglikse realiteit, ook binne die wêreld van kerk, soos wat huidige teologiese gesprekke, publikasies, seminare, en virtuele bedienings bevestig. Maar wat is virtualiteit presies ${ }^{6}$ Is dit 'n blote tegnologiese aanhangsel tot die realiteit, of dalk 'n nie-reële, kunsmatige wêreld wat vir vele as ontsnappingsroete uit die werklikheid dien? Kom ons klop aan

4 Alex Wilhelm skryf: “...tweets in 2009 grew some 1,400\%. Traffic to Twitter.com grew around 1,100\%, and total sent Tweets went up 1,400\%." http://thenextweb.com/socialmedia/2010/02/22/twitter-statisticsfull-picture/

$5 \underline{\mathrm{http} / / \mathrm{wwww} . i n t e r n e t w o r l d s t a t s . c o m / a f / z a . h t m}$. Vergelyk egter die inligting hieroor van die BBC by: http:// news.bbc.co.uk/2/hi/technology/8552410.stm.

6 Ter wille van terminologiese verheldering: "elektronies" hou verband met alle materiaal en data in wat elektries aangedrewe media gestoor en versend word, insluitend digitale informasie. "Digitaal" hou weer verband met inligting wat weer geberg, geprosesseer en versend word via digitale (binêre) apparatuur en rekenaar netwerke. Digitale materiaal bestaan virtueel indien dit in die kuberruim geberg en benut word. 
by Wikipedia, een van die grootste virtuele bronne van informasie, vir 'n omskrywing:

"A virtual world is a genre of online community that often takes the form of a computerbased simulated environment, through which users can interact with one another and use and create objects. Virtual worlds are intended for its users to inhabit and interact, and the term today has become largely synonymous with interactive 3D virtual environments..."7

Doug Estes, 'n Nuwe-Testamentikus in eie reg, reflekteer in 'n onlangse boek getiteld SimChurch (2009:Kindle) as volg oor die aard van virtuele wêrelde: "A virtual world is a created space where people can interact as if in the real world, but through some type of technological medium." Hy verduidelik die verskil tussen fiksionele en virtuele wêrelde as volg: "A fictional world is not the same as a virtual world because a fictional world is a mode of possibility and a virtual world is a mode of reality."

Binne digitaal gekonstrueerde realiteite, of soos wat Edward Castronova (2006) dit noem: sintetiese wêrelde, vind verskillende vorms van sosiale interaksie plaas. Enigiets vanaf webblaaie, blogs, MySpace, YouTube, SecondLife, Mixit tot by Twitter konnekteer mense op derduisende maniere en met uiteenlopende doelwitte. Inderdaad mag diegene wat verkies om nie aktiewe deelnemers aan sodanige virtuele interaksies te wees nie, dit as kunsmatige ontvlugtings vanuit die realiteit verstaan, maar dit verander nogtans nie aan die feit dat eietydse tegnologie ruim toegangspoorte bied tot sosio-virtuele wêrelde waarbinne mense interaktief betrokke is nie. Net soos wat mense binne die konkrete wêreld hul eie "ideale wêrelde" konstrueer en ook leefbaar maak deur middel van prosesse van "objektifikasie" en "internalisering," soos wat Peter Berger en Thomas Luckmann dit reeds in die 1960's beskryf het in hulle invloedryke werk: The Social Construction of Reality, skep mense ook bepaalde virtuele realiteite waar sinvolle interaksie tussen deelnemers in die kuberruim plaasvind, en wat hul daaglikse lewe in die sogenaamde "regte wêreld" grondliggend beïnvloed.

Daar bestaan 'n onlosmaaklike verband tussen antropologie en tegnologie. Bedoelende, regte mense van vlees en bloed is verantwoordelik vir tegnologiese ontwikkelings en daaropvolgende inhoudelike vormgewing van hierdie einste tegnologie. Dit is egter nie 'n neutrale, eenrigting proses nie. Tegnologie is menslike skeppings, maar dan ook skeppings wat veranderings te weeg bring aan ons selfverstaan en dié van ons omgewings. Daarom skryf Spyker (2008:Kindle):

"Technology is not our tools; it is how we create and use tools. In a nutshell, technology is part of what defines us; it is part of what makes us humans. More than that, the technologies we adopt affect the type of humans we become. The tools we choose to use and how we use them affect how we think, how we make decisions, how we relate to one another, how we construct knowledge, even how we think about God."

Spyker trap egter in 'n "spyker" van sy eie as hy eietydse tegnologiese verskuiwings slegs maar as ' $n$ informasie-revolusie tipeer. Kennis het inderdaad makliker bereikbaar, onmiddellik beskikbaar en ook goedkoper geword, te danke veral aan Google, Yahoo en Wikipedia. Tog is die nuwe digitale ruimtes meer as net bestaande of nuwe vorme van kennis wat in vinnige, meer verbuikersvriendelike verpakkings beskikbaar geraak het, of informasie wat slegs in nuwe elektroniese baadjies verpak word (Kindle en $i P a d) .{ }^{8}$ Die virtuele realiteit is'n multivlakkige, digitaal gefasiliteerde werklikheid waar die vraag na betekenis implisiet sowel as eksplisiet aan die orde

7 http://en.wikipedia.org/wiki/Virtual_world. 9 Julie 2010.

8 Die informasiekultuur hou ook verband met die era van die drukpers wat rondom die middel van die $15 \mathrm{de}$ eeu afskop met Gutenberg se drukpers. Van toe af was linieêr gedrewe massakommunikasie aan die orde van die dag. Ordelike, boekverpakte informasie was van toe af binne die bereik van gewone mense wat steeds in orale omgewings geleef het. 
van die dag is. Mense is met ander woorde met hulle wil, harte, emosies, asook met bepaalde spiritualiteite hier aanwesig. Die digitale werklikheid dien derhalwe as uitdrukkingsvorms van miljoene mense se bestaande en/of hergedefinieerde identiteite. Dit is hulle voorkeur kuierplek, werkplek en kerkplek.

\section{NUWE PARADIGMAS, NUWE WERKLIKHEDE!}

Paradigmaverskuiwings en nuwe wêreldbeelde is nie vreemde begrippe binne huidige teologiese diskoerse nie. Dit is juis akademies korrek om op hoogte te wees met hermeneutiese verskuiwings in groepe se werklikheidsverstaan deur die eeue en hoe dit onder andere ons interpretasie van die Bybel beïnvloed (vgl Lategan 2009:13ff). Op 'n hoër vlak van abstraksie is dit nodig om ook kennis te dra van algemene veranderings binne die geskiedenis van die mensdom vanaf ' $n$ orale kultuur, na 'n post-15de eeuse drukperskultuur, tot by die 19de eeuse informasiekultuur en ons huidige digitale kultuur (Miller 2004:19ff). Eweneens is dit waardevol om ingelyf te wees in debatte rondom die verskuiwings vanaf ' $n$ Kopernikaanse wêreldbeeld tot en met ons eietydse heliosentriese, digitale leefwêrelde, wat veral in Westerse denke uitdrukking gevind het in die Franse filosoof Rene Descartes se beroemde woorde: "cogito ergo sum" ("ek dink, daarom is ek"). Descartes se liggaam-gees onderskeid het Westerse denkprosesse grondig beïnvloed om die liggaamlike as die eintlike vorm van interaksie met die sintuiglike wêreld te verstaan, terwyl die siel as 'n abstrakte, minder reële vorm van bestaan beskou is. Die gevolg was 'n nuwe tipe rasionele denke, ook binne die teologie, wat onder andere veronderstel dat slegs dit wat ons by wyse van wetenskaplike eksperimente en historiese analogieë kan bewys kenbaar en eventueel ook eg is.

Rasionele denkparadigmas het deur die loop van die 20ste eeu toenemende teenstand gekry vanuit die geledere van denkers soos Lyotard en Derrida wat hulleself intellektueel verset het teen sodanige logosentriese- en ander verstaansmodelle. Uiteindelik het dit gelei tot ' $n$ hermeneutiese paradigmaverskuiwing wat algemene uitdrukking gevind het in die enigmatiese term: post-modernisme. ${ }^{9}$ Terwyl hierdie sambreelterm vir vele kerklikes ' $n$ negatiewe term is en vir ander ' $n$ reddingsterm, blyk dit dat die huidige digitale rewolusie vir vele weliswaar ' $n$ ontsnappingsroete bied weg vanuit die hoogs gekontroleerde en spesialis-gedrewe werklikheid van die modernisme.

Die epogmakende nuwe era van digitaliteit verteenwoordig 'n verskuiwing in miljoene se verstaan van hulself, ander, God, spasie en tyd. Dit word onder andere vergestalt in nuwe kenteorieë of epistemologieë, asook in nuwe aetiologieë (verklarings vir die oorsprong van objekte); futurologieë (sienings van die toekoms); metodologieë (nuwe vorms van doelwitbereiking), taal ('n nuwe "jargon" om nuwe tegnologie en andersoortige vorms van interaksie onder woorde te bring) en waardes wat op fundamentele vlak gestalte gee aan nuwe vorms van eksistensie. Anders gestel, die koms van hierdie nuwe media het nie slegs verbeterde hoëspoed tegnologie tot gevolg gehad nie; dit het terselfdertyd dramatiese verstellings meegebring aan ons eie verstaan van, en verskillende interaksies binne bestaande en nuut gekonstrueerde (digitale) werklikhede. Tereg skryf Watson (2008:Kindle): “Greater connectivity, brought about by technology, deregulation, globalization, low-cost travel and migration, is changing how people live, how people work and

9 Wikipedia (http://en.wikipedia.org/wiki/Postmodernism): "Postmodernism is a tendency in contemporary culture characterized by the rejection of objective truth and global cultural narrative. It emphasizes the role of language, power relations, and motivations; in particular it attacks the use of sharp classifications such as male versus female, straight versus gay, white versus black, and imperial versus colonial. Postmodernism has influenced many cultural fields, including literary criticism, sociology, linguistics, architecture, visual arts, and music." 
how people think."

Weliswaar is die wêreldverskuiwende impak van digitale tegnologie nie ewe sterk op almal nie. Dit is meer "voelbaar" binne die sogenaamde "Net Generasie" (sien afdeling 4) en minder op ouer generasies. Binne ons sosiale netwerk era van Web 2.0 is digitale werklikheide vir hierdie "Net Geners" gelyk aan die realiteit per se, terwyl die digitale media vir ander persone en groepe ten minste meer effektiewe hulpmiddels ter ontsluiting van informasie bed. Nogtans is die digitale werklikheid waarbinne ons onsself bevind onvermybaar. ' $n$ Onlangse berig in Harvard Business Review deur Jeanne Meister en Karie Willyerd praat alreeds van 'n nuwe tipe "virtual leadership" waar internasionale besighede virtuele vergaderings, aanlyn forums en groepbesprekings met kollegas regoor die aarde hou met behulp van tegnologie soos WebEx en TelePresence. ${ }^{10}$ Selfoontegnologie is in hierdie verband ook ' $n$ fenomenale globale verbindingsmedium. Selfs in 'n ontwikkelende land soos Suid Afrika beskik $80 \%$ mense reeds oor selfone, soos wat 'n onlangse Markinor ondersoek uitgewys het (Joubert 2009:34)

Een van die heursitiese sleutels ter verstaan van die digitale era is 'n doelbewuste soeke na "connectivity," oftewel konnektiwiteit. Konnektiwiteit verwys nie net na die spoed, bandwydte of verbindingsvermoëns wat nuwe digitale tegnologieë bied nie, maar ook na die deelnemers aan hierdie nuwe werklikheid se uiteenlopende behoeftes aan onderlinge skakeling. Daarom dat hulle taal deurdrenk is met terme soos interaktiwiteit, skakeling ("links"), netwerke ("social networks"), vriendskap, volgelinge ("followers"), ensomeer. Kortom, dit gaan oor eiesoortige sinvolle "peer-to-peer communication." Ongetwyfeld hou die virtuele wêreld groot belofte in ten opsigte van nuwe vorms van konnektiwiteit. Soos wat Thomas Kuhn, die mees invloedryke nadenker oor wetenskaplike paradigmaverskuiwings, ons geleer het, is dit juis die beloftes wat nuwe teorieë, en in ons geval: digitale media, bied, wat telkens 'n "eksodus" na 'n nuwe universum tot gevolg het, nie noodwendig die reële veranderings en verbeterings of, in ons geval, die verhoogde kwaliteit van verhoudings, wat dit eventueel bied nie.

Die groot soektog vir vele binne ons post-moderne, digitaal bemiddelde wêreld, is om uit hulle kokonne van alleenheid, onbelangrikheid en "disconnectedness" te ontsnap. Die behoefte om iewers te behoort, is een van die basiese menslike behoeftes, soos wat die bekende sielkundige, Martin Seligman, Edward Diener, en ander navorsers binne die skool van "positiewe sielkunde" bevind het. In hierdie verband skryf Janet Surrey (aangehaal in Jessy Rice, 2009:Kindle) dat konnektiwiteit "the core of psychological wellbeing" is, sowel as "the essential quality of growthfostering and healing relationships. In moments of deep connection in relationship, we break out of isolation and contraction into a more whole and spacious state of mind and heart."

Facebook is waarskynlik die belangrikste virtuele ruimte binne die www.doolhof wat vir miljoene die belofte bied van 'n nuwe tuiste waar individue op hul eie terme kan behoort en eiesoortige konneksies met hulle "vriende" kan vorm. Reeds teen die middel van 2009 is 850 miljoen foto's per maand op Facebook opgelaai. Die gemiddelde Facebook lid deel sy of haar lewe tans met ten minste 120 ander "Facebook friends." Jessy Rice (2009) verduidelik hierdie idealistiese onderbou van Facebook in terme van die beeld van ' $n$ tuiste of ' $n$ "home" (vergelyk ook Friesen, 2009):

"Home is where we keep all the stuff that matters most to us" (Facebook dien as uitstalplek van mense se fotos en dit bied onder andere ook spasies waar hulle politieke en religieuse waardes verwoord kan word)

"Home is wherever we find family" (Facebook fasiliteer vinnige "homelike moments with family and friends from around the world, despite any geographical barriers.")

10 http://blogs.hbr.org/cs/2010/06/leading_virtual_teams_to_real.html?utm_source=feedburner\&utm medium $=$ feed\&utm campaign $=$ Feed $\% 3 \mathrm{~A}+$ harvardbusiness $\% 2 \mathrm{Fcs}+\% 28$ Conversation + Starter + on $+\overline{H B R}$. org\%29 (30 Junie 2010). 


\begin{abstract}
"Home is where we feel safe because we can control the environment" (Indiwidue se behoefte aan aktiewe, instrumentele beheer word op Facebook aangespreek).

"Home is where we can 'just be ourselves."' (Facebook is die ideale virtuele ruimte vir indiwidue om 'n ideale beeld te skep van hulself en dit ook te projekteer na hul vriende sonder direkte eksterne inmenging.)
\end{abstract}

\title{
4. NIE LANGER NET INFORMASIE-JAGTERS NIE: DIE NUWE “NET GENERASIE”
}

Die digitale era is nie 'n uniforme, gelyktydige proses wat orals op dieselfde wyses en teen dieselfde spoed plaasvind nie. Dit is veral die jonger generasie wat digitaal gesosialiseerd is, soos wat Don Tapscott (2009:xi-xii) onder andere bevind. In 'n uitgebreide ondersoek, getiteld "The Net Generation: A Strategic Investigation", waar hy en sy span tussen 2006-2008 onderhoude met 10,000 mense gevoer het, praat Tapscott juis van "Net Geners" as die geslag wat volledig met die internet opgegroei het. "In 2008 the eldest of the generation turned 31 . The youngest turned 11. Around the world the generation is flooding into the workplace, marketplace, and every niche of society. They are bringing their demographic muscle, media smarts, purchasing power, new models of collaborating and parenting, entrepreneurship, and political power into the world (2009:9)." Hy kon hier ook bygevoeg het, hul eie spiritualiteit!"

Kritiek op hierdie sogenaamde "Net Generasie" bly egter nie uit nie, soos wat Tapscott tereg aandui. Hulle word soms uitgewys as minder intelligent as vorige generasies van soortgelyke ouderdom. Hulle word "screenagers" genoem wat verslaaf is aan digitale media en wat hulle interpersoonlike vaardighede verloor het. Ook word beskuldigings van diefstal, skaamteloosheid, gewelddadigheid, selfbehaaglikheid en luiheid in die rigting van hierdie jonger generasie geslinger. Tog bevind Tapscott dat die meeste van hierdie aannames vals is. Hy skryf: "As the first global generation ever, the Net Geners are smarter, quicker, and more tolerant of diversity than their predecessors. They care strongly about justice and the problems faced by their society and are typically engaged in some kind of civic activity at school, at work, or in their communities (2009:6). Hy vind vervolgens 'n aantal karaktereienskappe wat tipiese "Net Geners" beskryf en wat hul onderskei van hul "Baby Boomer" ouers, naamlik: "They prize freedom and freedom of choice. They want to customize things, make them their own. They're natural collaborators, who enjoy a conversation, not a lecture. They'll scrutinize you and your organization. They insist on integrity. They want to have fun, even at work and at school. Speed is normal. Innovation is part of life." (2009:6-7).

Tapscott meen dat die kritiek op die nuwe digitale generasie eerder te make het met ander mense se onbekendheid met nuwe tegnologie, eerder as dat dit gebaseer is op feitelike navorsing. Die nuwe "Net Generasie" gebruik tegnologie immers heeltemal anders as hul voorgangers. Vir hulle is dit nie slegs nuttige kommunikasiemiddels nie, maar konneksie-platforms. "Net Geners are transforming the Internet from a place where you find information to a place where you share information, collaborate on projects of mutual interest, and create new ways to solve some of our most pressing problems" (Tapscott 2009:40). Hulle doen dit deur die skep en deel van nuwe interaktiewe inhoude op blogs en ander hulpmiddels wat Web 2.0 se sosiale netwerk platforms aan hulle bied. ${ }^{11}$ Dit is nie langer die dagblaaie, TV nuus of boeke wat hierdie generasie se hoofinformante is nie. Nog minder is dit gesagsinstellings soos tradisionele kerke, of outoritêre godsdienstige leiers. "Old time religion" het in hulle omgewing ook plek gemaak vir "online religion" met virtuele kerke, interaktiewe Christelike gespreksforums en eredienste as hul geestelike kuierplekke.

11 Web 2.0 verwys vir baie na die nuwe internet tegnologie wat mense in staat stel om hul eie inligting op die internet te publiseer en interaktief te deel. Dit gaan dus oor sogenaamde "user-generated content." 
Die digitale era word tans gekenmerk deur 'n groeiende generasie gaping, wat bepaalde implikasies vir kerklike bediening in die toekoms inhou in terme van die uiteenlopende bedieningsbehoeftes van verskillende generasies. Verskillende sienings van die rol, funksies en aanwending van nuwe tegnologieë is volgens George Barna een van die vernaamste redes hiervoor. Navorsing deur die Barna groep in 2009 bevind dat 22\% van mense in die ouderdomgroep 18-24 die nuutste tegnologie as 'n hoë prioriteit in hul lewens beskou, terwyl slegs $9 \%$ van volwassenes bo die ouderdom van 25 dit as 'n prioriteit sien. ${ }^{12}$ Nog 'n rede vir die generasie gaping is waarskynlik omdat die breinontwikkeling van hierdie "Net Generasie" verskillend plaasvind van dié van hul voorgangers. ${ }^{13}$ Leonard Sweet noem tereg dat daar inderwaarheid net drie tipe mense op aarde is: "foreigners, natives and immigrants." Daardie volwassenes wat weier om te emigreer na hierdie nuwe digitale beskawing, "...constructed with sand (silicon), glass (fiber), air (wireless) and DNA (genes)" (Sweet 1999:147), sal bes moontlik gestrand agterbly op ' $n$ krimpende eiland van digitale ongeletterdheid. ${ }^{14}$

Binneonssnelveranderendewêreld, waar digitaliteit'n omvattende nuwewerklikheidsverstaan veronderstel wat alle vorms van realiteit grondig raak, moet ons bedag wees op bepaalde vangstrikke wat dit inhou. Tereg merk Neil Postman (1993:5) op dat daar baie eenogiges is binne nuwe werklikhede "...who see only what new technologies can do and are uncapable of imagining what they will undo." Eietydse media en die gevolglike leefstyle en wêreldbeelde wat dit fasiliteer is definitief nie neutraal nie. Media, na luid van Marshall McLuhan se bekende uitspraak, is immers die boodskap self; "the medium is the message." Sodra enige medium verander, raak dit die boodskap ook op een of ander manier. Ons skep ons media en ons word gevorm deur ons media. In die woorde van Shane Hipps (2009:45): "The tools we use to think actually shape the way we think. The same applies to our faith as well.

\section{DIE IMPAK VAN VISUALITEIT}

'n Verdere uitdagings vir die nuwe digitale era, bo en behalwe die feit dat veral die sogenaamde "Net Generasie" te veel persoonlike informasie op sosiale netwerke deel wat hul toekomstige privaatheid kan ondermyn, is die oormatige klem op visualiteit. Visuele beelde en geskrewe woorde se emotiewe impak is uiteenlopend van aard en word ook in verskillende dele van die brein geprosesseer.

"Images initially make us feel rather than think. They can pin the logical side of your brain to the back of your skull, which is why imnage-based advertising is so effective. Images don't invite you to argue; they give you an experience. In contrast, the printed word makes us think and question... Our brains process printed words and images in different ways. The printed word is processed primarily in the left hemisphere of the brain, which specializes in logic, sequence and categories. Images are processed primarily in the right hemisphere, which specializes in intuition and holistic perception, rather than linear analysis." (Hipps 2009:76-77).

12 http://www.barna.org/barna-update/article/14-media/212-new-research-explores-how-technology-drivesgeneration-gap?q=media+technology

13 Alhoewel sodanige navorsing nog in 'n vroeë stadium is, lyk dit asof hierdie generasie hoër ontwikkelde ruimtelike en visuele vaardighede as vorige generasies het (Tapscott 2009:97-120).

14 Goeie nuus egter is dat nuwe navorsing ook aantoon dat die volwasse brein steeds verder kan ontwikkel. Susan Begley (2007:8) sê in hierdie verband: "The brain can indeed be rewired... It can activate longdormant wires and run new cables like an electrician bringing an old house up to code.... The adult brain, in short, retains much of the plasticity of the developing brain, including the power to repair damaged regions, to grow new neurons, to rezone regions that performed one task and have them assume a new task, to change the circuitry that weaves neurons into networks that allow us to remember, feel, suffer, think, imagine and dream." 
Hipps bevind selfs: Electronic media not only nurture the right-brain' it can suspend activity in the left brain" (p. 145). Dink net watter implikasies hou hierdie feit in vir die lees, hoor en korrekte verstaan van die Bybel! Kortom, kerklike bedienings sal kreatiewe maniere moet vind om die Bybel relevant en verantwoordelik aan die woord te laat kom binne digitale werklikhede.

\section{DIE AFWESIGHEID VAN SPESIALISTE EN KENNERS}

Die digitale realiteit fasiliteer dikwels kunsmatige beelde van die realiteit en systap daardie fakulteite in ons brein wat noodsaaklik is om 'n groter potensiaal tot kritiese denke aan te wakker. Derhalwe kan digitale ruimtes soms manipulerend en eensydig raak. In dieselfde asem kan die nuwe "we-think" mentaliteit van die virtuele wêreld, ten spyte van bepaalde voordele wat dit inhou (Aldus Leadbeater, 2009:32ff), ${ }^{15}$ 'n tipe werklikheid skep waar alle opinies, standpunte, idees en waarnemings op presiese dieselfde vlak staan (vgl Joubert 2009:22-24:). Of jy nou 'n jong "Net Gener" is wat willekeurig jou (anonieme) opinie gee, en of jy'n deurwinterde direkteur van 'n mediese firma is, alle menings oor, sê nou maar een of ander nuwe mediese produk, loop die gevaar om op presies dieselfde vlak geëvalueer en benut te word deur "we-thinkers." Naïewe opinievorming van en deur die massas kan 'n ongesonde kollektiewe digitale kultuur tot gevolg hê wat veral die "Net Generasie" sleg kan benadeel in terme van hul sosiale en emosionele ontwikkeling. Daardie "everyone is a media outlet" sindroom (vgl Shirky 2008:55ff), kan selfs aanleiding gee tot verskillende vorme van digitale banaliteit ten einde die virtuele ruim se nimmereindigende statistiese gewildheidsleer verder uit te klim. Derhalwe is daar 'n dringende behoefte aan 'n herwaardering van spesialiste en meningsvormende kenners binne kuberruimtes wie se opinies eenvoudig meer gewig moet dra as diegene wat na willekeur ongeïnformeerde, naïewe standpunte digitaal loslaat.

\section{NAGEBOOTSTE KONNEKTWITEIT EN ONMIDDELLIKE BEHOEFTEGEDREWENHEID}

'n Ander knik in die pad van die digitale era is die opkoms van 'n nuwe geslag indiwidualistiese stamlede, oftewel "tribal individualsits." Uiteraard kom hulle veral uit die geledere van die sogenaamde "Net Geners" (sien afdeling 4). Sowel Shane Hipps as Jessy Rice wys tereg op die kunsmatigheid van vele vorms van konneksie binne die www. wêreld. Dit vervang dikwels noodsaaklike gesig tot gesig relasies ten gunste van gemanipuleerde "vriendskapsverhoudings", maar sonder diep konnektiwiteit wat egte onderlinge verbondenheid tot gevolg het. Kortom, dit skep hoogs selfsugtige wêrelde waar: "The near become far, and the far are brought near" (Hipps 2009:107). Lee Siegel (2008:6) gaan selfs so ver om die kuberruim: "the first social environment to serve the needs of the isolated, elevated, asocial individual" te noem. ${ }^{16}$ Hierbinne kan emosies, ervarings en gesprekke vanaf ' $n$ veilige afstand bestuur en beheer (gemanipuleer?) word. Dit kan indiwidue spoedig afstomp vir egte omgee en onselfsugtige diensbaarheid teenoor hul medemens wat juis met persoonlike ontberings en opofferings gepaard gaan. Trouens, die groot versoeking van die virtuele wêreld is 'n sogenaamde "convenience factor" waar indiwidue

15 Leadbeater (2009:32) skryf: "we will not make sense of the mass of information generated by the web on our own; our only hope is to employ our shared intelligence. The more people contribute, the more we need to collaborate. The more people use the web to say 'I think... this, that and the other,the more we will need 'We-think...' to create some order, to sort the wheat from the chaff." Groter deursigtigheid is 'n groot voordeel van hierdie subtiele verskuiwing "from 'me' to 'we", (Watson 2008, Kindle).

16 Siegel (2008:8) skryf dat sy kritiek op die konvensies van die internet gewoonlik met groot teenstand en beledigings op blogs begroet word." Criticize the Internet and you are accused of criticizing democracy.

The triumphal, self-congratulating rhetoric surrounding the Internet has made it impervious to criticism." 
die meesters van hul eie klein wêrelde en die bestuurders van hul voorkeur-maniere van konnektiwiteit word. Sodanige gemanipuleerde wêreld boots dan slegs verhoudings na, maar dan sonder die seer, swaar en pyn van dag-tot-dag saamleef met ander.

Uiteraard is die behoefte aan onmiddellike satisfaksie binne die kuberruim veral te sien in die nimmereindigende gewildheid van pornografiese webtuistes. Dit blyk aan die begin van 2010 dat sowat $12 \%$ van alle webtuistes pornografies van aard is. Sowat $35 \%$ van alle materiaal wat jaarliks vanaf die internet afgelaai word is pornografie. Hierdie industrie genereer jaarliks sowat $\$ 4,9$ miljard. ${ }^{17}$ Een van die nuwe tendense sedert 2005 op hierdie gebied is die verskyning van sogenaamde "sosiale pornografie" waar besoekers pornografiese inhoude self genereer en gratis op webruimtes versprei. Sodanige webtuistes bereik tans by die 17 miljoen unieke besoekers daagliks. 18

\section{8. 'N SPIEËL EN SKADU TEGELYK: GELOOF IN 'N DIGITALE ERA}

\section{a. Die digitale werklikheid is ook diep geestelik}

Die internet blink uit in die skepping van 'n "weird, wonderful and what's next" werklikheid. Tog moet ons nie die fout maak, veral wat godsdiens betref, om te dink digitale werklikhede en dag-tot-dag werklikhede is onafhanklik van mekaar nie. Al weet niemand presies hoe hierdie simbiotiese relasie vorentoe gaan uitspeel nie, is Dawson en Cowen in die kol as hulle sê: "Cyberspace is not quite as unusual a place as sometimes predicted. Life in cyberspace is in continuity with so-called 'real life,' and this holds true for religion as well. People are doing online pretty much what they do offline, but they are doing it differently (2004:2). In vele opsigte figureer die digitale wêreld beide as ' $n$ spieël en 'n skaduwee vir religieuse aktwiteite tegelyk. "That is, there is very little in the real world that is not electronically reproduced online, and very little online that has no offline foundation or referent."

Godsdiens het 'n groot staanplek op die internet, soos wat die impak van plaaslike webwerwe soos ekerk (www.ekerk.co.za) in Suid Afrika onder andere bevestig. Naas webblaaie met ' $n$ pornografiese inhoud, is religieuse webblaaie tans van die mees besoekte ruimtes. Geen wonder nie dat teologiese navorser, Brenda Brasher (2004), praat van 'n nuwe reformasie wat religieuse tradisies in die gesig staar as gevolg van, wat sy noem: "die tsunami van spiritualiteit" wat die kuberruimte getref het en wat alles in die pad oorspoel. Vandag kan indiwidue ter eniger tyd en enige plek op aarde toegang tot "the sacred" hê. Boonop word groter religieuse verdraagsaamheid en diversiteit hier gefasiliteer as in die regte wêreld. Tog bly die tergende vraag, ook vir Brasher, of koinonia ten diepste gefasiliteer word in die kuberruim?

\section{b. "Religion online" versus "online religion": Staan die internet teenoor geloofsbeoefing in plaaslike kerke?}

Is daar 'n verskil tussen "religion online" en "online religion?" Volgens Dawson \& Cowen (2004:6) is "online religion" gelyk aan "the provision of information about and/or services related to various religious groups and traditions." Dit sluit in webblaaie en inligtingsbrosjures van gemeentes en geloofsorganisasies. "Religion online" op sy beurt "invites Internet visitors to participate in religious practices." Dit mag enigiets omvat vanaf aanlyn gebede, Bybelstudies,

17 Aldus MBA online: http://www.blogtactic.com/2010/06/internet-pornography-statistics-2010.html $18 \mathrm{http}: / /$ woorkup.com/2010/06/24/the-state-of-social-porn/ In Suid Afrika bevind 'n onlangse ondersoek onder hoërskoolleerlinge, waarvolgens 9 uit 10 kinders toegang tot selfone het en 7 uit 10 toegang het tot die internet, dat $92 \%$ van respondente seks op TV geleer het en dat 2 uit 5 al selfoonboodskappe met seksuele inhoud ontvang het- Rapport, Sondag 6 Junie 2010. 
kerkdienste tot berading. Uiteraard pas vele vorms van godsdiens op die web iewers tussen hierdie twee kategorieë in. Dit bied sowel informasie as partisipasie; oftewel, dit bied informasie ten opsigte van reële godsdienstige aktiwiteite én die belofte van deelname aan ' $n$ volledige en omvattende "plaaslike gemeente" op die internet.

Navorsing rakende die rol van godsdiens op die internet stel allerlei interessante nuwe vrae aan die orde, soos of normale religieuse aktiwiteite ondersteun, belemmer of aangewakker word deur die internet; andersyds of indiwidue se godsdienstigheid hulle internetgebruik raak, en of godsdienstige affiliasie enige beduidende impak op indiwidue se gebruik van die internet het. In 'n kort studie in hierdie verband verwys Christopher Paine (2009) na 'n meningspeiling waar respondente se aanlyn aktiwiteite ter ondersteuning van hul godsdienstige gebruike getoets is. Hieruit blyk dit onder andere dat persone die internet graag benut om geestelike musiek af te laai, asook om geestelike leiding te gee en te ontvang via epos (2009:10). Volgens Paine wil dit egter voorkom asof "people who are actively engaged in religious activities simply may be using the Internet for seeking religious information rather than buying religious items or planning religious activities" (2009:11).

Op hulle beurt bevind die bekende kerknavorsers, George Barna en David Kinnaman in 'n kort studie in 2008 oor die internetgebruik van gelowiges dat "people within the Christian community are just as immersed in (and dependent upon) digital technologies and social networks as are those outside of it." Trouens, "matters of faith played very little role in differentiating people's technological habits." Ewe interessant is die toename wat Barna-hulle bespeur in ouer persone wat digitale preke luister, algemeen bekend as "podcasts". Sowat 45 miljoen Amerikaners maak naamlik gebruik van digitale media een maal per week om 'n preek af te laai. Tog is die tegnologiese gaping tussen verskillende ouderdomsgroepe, ook in die kerk, steeds beduidend groot. $^{19}$

\section{c. Digitale bedienings is nie aanhangsels tot die "eintlike" kerklike bedienings nie}

Die benutting van tegnologie vind toenemend ingang in kerklike bedienings. Die dae dat die kerk nog "stuck on the print autopilot" is (aldus Len Sweet in sy voorwoord in Stephenson 2006), is aan die verbygaan. Al hoe meer kerke aanvaar die gebruik van elektroniese mediaborde, rekenaars en video's deesdae tans as vanselfsprekend. Publikasies oor die effektiewe benutting van nuwe tegnologie in kerke wemel ook op boekrakke. Barna bevind juis in 'n studie oor die groeiende gebruik van tegnologie in kerke (2005):

“... that church budgets for technology resources are increasing. 'As church staff and congregational leaders become more comfortable with, and dependent upon new technologies for communication, they are expecting their church to stay relevant in its capacity to convey messages in ways that are common in our culture. Some seminaries are offering courses and even degrees in the use of media for ministry, and increasing numbers of churches are creating staff positions for technology specialists.'"20

19 "The technology gaps by generation were impressive. The researchers categorized "mainstream" technology as those used by $50 \%$ or more of the population, while "emerging" technology represented penetration of $20 \%$ to less than half. Among Elders (ages 62+), two out of the 15 areas were deemed mainstream (email and search), while another two domains were emerging (IM and online purchases). Boomers (ages 43 to 61) had two mainstream categories and four emerging areas. Busters (ages 24 to 42) had four mainstream and four emerging technologies. The nation's youngest adults, Mosaics who are 23 and under, were easily the furthest along in their adoption of these technologies. Mosaics had eight mainstream categories and another three deemed to be emerging. In other words, out of the 15 areas of technology assessed in the research, Elders widely embraced or were becoming comfortable with four, Boomers with six, Busters with eight, and Mosaics with 11." http://www.barna.org/barna-update/ article/14-media/36-barna-technology-study-social-networking-online-entertainment-and-churchpodcasts? $=$ =media+technology.

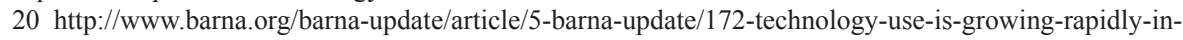


Digitale bediening is vir die meeste organisasies en kerke steeds egter net 'n "add-on," nie 'n sentrale bediening as sodanig nie. Webblaaie dien hoogstens as digitale afkondigings, of as ' $n$ algemene informasieblad, maar nie as uitdrukking van 'n goed deurdagte, duidelik gefokusde digitale media bediening nie. Stephenson (2006:Kindle) verwoord die moontlike rede hiervoor as volg: "Most people in church leadership positions know very little about internet ministry." Min kerke is derhalwe bereid om mense te betaal om deeltyds of voltyds sodanige digitale bedienings te bedryf. Daar is steeds kerklike boufondse en orrelfondse in plek, maar min kerke beskik oor behoorlike digitale begrotings.

- Volgens Stephenson kan digitale bedienings:

- "Improve church communication quickly, easily and inexpensively

- Empower lay volunteers for active participation

- Minister lay people at any time and in any place

- $\quad$ Allow your sermons, devotions, and Bible studies to continue to minister for years to come

- Expand your ministry to reach people around the world."

Vir gemeentes om tans nie 'n virtuele bediening in plek te hê nie, is amper net so goed as om geen telefone by die kerk te hê, of geen gelyste telefoonnommers in telefoongidsde nie. Om te meen "digitale gevisualiseerdheid" (die drukpers era sou hier gepraat het van "geletterdheid") val buite ' $n$ gemeente se skopus, is sinoniem aan ongeletterdheid in die drukpers-kultuur!

\section{d. Begryp die filosofie rondom bediening in die digitale era}

Nuwe publikasies fokus op aspekte soos die filosofie, praktyk en die voor-en nadele van die benutting van media in Christelike bedienings. Tereg wys Len Wilson (2008:Kindle) in hierdie verband daarop dat media binne die digitale kultuur primêr narratief van aard is. "This narrative purpose is in direct contrast to mass print culture... Its strength in storytelling is due to powerful engagement of the senses on multiple levels through visual and aural imagery." As gevolg van die nuwe interaktiewe aard van Web 2.0 media is die kerk in die gunstige posisie om die evangelie op nuwe, verbeeldingryke maniere te kommunikeer; iets wat voorheen net nie moontlik was nie. Hierbinne word daardie tipiese vraag van die "Baby Boomer Generasie": "staan die benutting van media dalk in die pad van die boodskap?" vervang met 'n veel beter vraag: "which forms of communication do we believe are worthy of communicating the gospel?" Eersgenoemde vraag spruit voort vanuit die wêreld van die drukpers-kultuur, terwyl laasgenoemde gewortel is binne die "image driven" narratiewe kultuur van die digitale era.

Binne die digitale era is media nie 'n luukse nie. Dit is eerder volgens Wilson "an emerging, fundamentally new system of communication, equal to oral and written word... Media then, should not be treated as operational support, but as ministry that uses video, audio, graphics, text, the Internet, and other emerging technology applications to communicate the gospel. The more digital, narrative, participatory, and immersive, the better."

Len Wilson (2008:Kindle, hoofstuk 2) lig vier belangrike maniere uit hoe om digitale media binne die kerk te verstaan, te wete

(i) "Media as the arts." Deur middel van die artistieke skoonheid van verskillende kunsvorms is God se woord vir eeue lank verkondig. Trouens, pous Gregorius het reeds aan die begin van die sewende eeu die kunste as die primêre media beskou om oningeligtes aangaande die Christendom te onderrig. Wilson haal Frederich Buechner aan wat sê die sterkte prediking in ons generasie is afkomstig "from the poets, playwrights and novelists," en gaan dan voort. "He almost got it right, with amends for his print-age

churches?q=media+technology 
bias. The most powerful preaching today is actually coming from the filmmakers, the stand-up comedians and the producers- the storytellers of the digital age. As die kultuur van ons dag kuns gebruik, al gebeur dit ook binne die sogenaamde "pop art" kultuur, dan moet die kerk juis ook hier aanwesig wees.

(ii) "Media as information." Die mikpunt hier vir die kerk is nie soseer om informasie te versprei nie, maar eerder om media as ' $n$ transformasie-middel te benut om mense na Christus se beeld te hervorm. Dit gaan dus nie oor blote kognitiewe inligting nie. "Effective or excellent media for this age engages not only the mind but also the heart and soul"

(iii) "Media as mission or evangelisation." Relevante bedienings moet die taal van die kultuur van die dag te praat ten einde mense deel van Christus se geloofsfamilie te maak. Tog moet die kerk ligloop vir 'n soort dualisme, in die sin dat eietydse media slegs as evangelisasiemiddel die kulturele taal van die wêreld praat terwyl normale kerklike praktyke onveranderd op ou maniere voortgaan. 'n Geïntegreerde interne en eksterne digitale kommunikasie-matriks is dringend nodig.

(iv) "Media as cultural language." Effektiewe media aanwending "must mediate the presence of the church in the world, for the sake of transforming the culture." Die kerk beskik oor die mees radikale, lewensveranderende stories om te vertel vanuit die Bybel. Derhalwe is insig in ons wêreld dringend nodig ten einde die Woord van God effektief te vertaal en te verwoord/verbeeld in die kulturele jargon van die digitale era.

\section{SLOT}

Die aanbreek van die digitale era beteken nie, soos wat sommige kuber-profete voorspel het, dat die werklikheid soos wat ons dit tans ken, finaal tot 'n einde gekom het nie. Vele bestaande interaksies, instellings en gebruike in ons wêreld sal steeds onveranderd voortgaan, soos wat John Naisbitt (2006) tereg opmerk. Verandering gebeur nooit reglynig en gelyktydig nie; dit vind voortdurend plaas binne 'n kultureel-antropologiese kontinuum. Tog is Estes (2009) net gedeeltelik in die kol as hy sê: "The real world is here to stay, though the internet remains a large part of our collective society." Digitaliteit is nie net ' $n$ aanhangsel of 'n effektiewe nuwe tegnologiese hulpmiddel tot die bestaande realiteit nie; dit is terselfdertyd ook ' $n$ radikale ingreep in, en aanpassing van (ons verstaan van) die werklikheid. Niemand kan aan die globale implikasies en die gepaardgaande grondvlak-impak van die digitale era ontsnap nie. Om elke hoek en draai het dit ' $n$ radikale effek op mense, vanaf inligting verspreiding tot by vermaak en spiritualiteitsvorming.

Ons is geroep om ons kultuur te help transformeer as eietydse navolgers van Christus. Dalk moet ons hier gaan kers opsteek by Maarten Luther wat die nuwe media van sy dag, naamlik die drukpers, effektief aangewend het om die Reformasie deur te voer. God se koninkryk moet met styl aanbreek binne ons uitdagende digitale era. Tereg sê Wilson (2008): "Our job as messengers of the gospel, is to speak in whatever language the culture is speaking." Die digitale era bied ruim nuwe geleenthede aan die kerk tot nuwe vorms van samewerking oor bestaande grense heen; die deel van nuwe informasie en tegnologie ten einde die evangelie vinniger en meer relevant uit te dra, en die bedryf van nuwe kollektiewe aksies. Kom ons leef dan ook digitaal!

\section{GERAADPLEEGDE BRONNE}

Begley, S. 2007. Train your Mind, Change your Brain: How a New Science Reveals our Extraordinary

Potential to Transform Ourselves. Balantine Books: New York.

Berger, P. L. \& Luckmann, T. 1967. The Social Construction of Reality: A Treatise in the Sociology of 
Knowledge. Anchor: New York.

Brasher, B. E. 2004. Give me that Online Religion. Rutgers University Press: New Jersey/London.

Castronova, E. 2006. Synthetic Worlds: The Business and Culture of Online Games. Chicago: University of Chicago Press.

Dawson, L. L \& Cowan, D. E. (Reds.) 2004. Religion Online: Finding Faith on the Internet. Routledge: London.

Estes, D. 2009. SimChurch: Being the Church in the Virtual World. Zondervan: Grand Rapids. (Kindle Weergawe)

Friesen, D. J. 2009. Thy Kingdom Connected: What the Church can Learn from Facebook, the Internet, and other Networks. Baker Books: Grand Rapids.

Hipps, S. 2009. Flickering Pixels: How Technology Shapes your Faith. Zondervan: Grand Rapids.

Joubert, S. J. 2009. Jesus - 'n Radikale Sprong. Koninkryk, Kerk en Wêreld: Waar Pas Ek In? Vereeniging: Christelike Uitgewers Maatskappy.

Kuhn, T. S. 1962. The Structure of Scientific Revolutions. University of Chicago Press: Chicago.

Lategan, B. 2009. New Testament Hermeneutics (Part 1): Defining Moments in the Development of Biblical Hermeneutics, in Du Toit, A. B. (red), Focusing on the Message. New Testament Hermeneutics, Exegesis and Methods. Pp. 13-63. Protea Book House: Pretoria.

Leadbeater, C. 2009. We-Think: Mass Innovation, not Mass Production. (2 ${ }^{\text {nd }}$ ed) Profile Books: London.

Miller, M. R. 2004. The Millennium Matrix: Reclaiming the Past, Reframing the Future of the Church. JoseyBass: San Francisco.

Naisbitt, J. 2006. Mind Set: Reset your Thinking and See the Future. HarperCollins: New York.

Paine, C. C. 2009. "Exploring the Relationships Between Religion and Internet Usage." Paper presented at the annual meeting of the International Communication Association, New York City. 2009-05-25 from http://www.allacademic.com/meta/p14224_index.html.

Postmann, N. 1993. Technopoly: The Surrender of Culture to Technology. Vintage Books: New York.

Rice, J. 2009. The Church of Facebook: How the Hyperconnected are Redefining Community. David C. Cook: Colorado Springs. (Kindle Weergawe).

Siegel, L. 2008. Against the Machine: Being Human in the Age of the Electronic Mob. Spiegel \& Grau: New York.

Shirky, C. 2008. Here Comes Everybody: The Power of Organizing without Organizations. Penguin: New York.

Spyker, S. K. 2007. Technology \& Spirituality: How the Information Revolution Affects our Spiritual Lives. Skylight Paths Publishing: Woodstock. (Kindle Weergawe).

Stephenson, M. M. 2006. Web-Empower your Church: Unleashing the Power of Internet Ministry. Nashville: Abingdon Press. (Kindle Weergawe).

Sweet, L. 1999. SoulTsunami: Sink or Swim in New Millennium Culture. Zondervan: Grand Rapids.

Tapscott, D. 2009. Grown Up Digital: How the Next Generation is Changing your World. McGraw Hill: New York.

Watson, R. 2008. Future Files: 5 Trends that will Shape the next 50 Years. Nicholas Brealey: London. (Kindle Weergawe).

Wilson, L (with Jason Moore). 2008. The Wired Church 2.0 Nashville: Abingdon Press. (Kindle Weergawe).

\section{TREFWOORDE}

Digitale era

Digitale kerk

Virtuele era

Virtele bediening

\section{KEYWORD}

Digital ear

Digital church

Virtual era

Virtual ministry
Prof S J Joubert

Navorsingsgenoot, Departement

Nuwe Testament

Universiteit vand die Vrystaat,

Bloemfontein

Posbus 10186

Aston Manor

Sel: 0834882822

E-pos; sjoubert12@gmail.com 